Bangladesh J. Bot. 44(2): 223-236, 2015 (June)

\title{
SUBLITTORAL SEAWEED FLORA OF THE ST. MARTIN'S ISLAND, BANGLADESH
}

\author{
Abdul Aziz, Syntheia Towhidy and Md Almujaddade Alfasane \\ Department of Botany, University of Dhaka, Dhaka-1000, Bangladesh
}

Key words: Sublittoral, Seaweeds, Rhodophyceae, Chlorophyceae, Phaeophyceae, St. Martin's Island, Bangladesh

\begin{abstract}
Investigation on the sublittoral seaweed flora collected from 0.5 to $10 \mathrm{~m}$ depth during late March and April, 2013 from six localities around the St. Martin's Island, Bangladesh has revealed the presence of 39 seaweed taxa, 12 under Rhodophyceae, 11 under Chlorophyceae and 16 under Phaeophyceae. Of these Avrainvillea amadelpha (Montagne) Gepp et Gepp (green), Pocockiella variegata (Lamx.) Papenfuss, Spatoglossum asperum J. Ag., Spatoglossum variabile Figari et De Notaris and Sargassum pallidum (Turner) C. Agardh (browns) are new records for Bangladesh.
\end{abstract}

\section{Introduction}

Bangladesh coast is $710 \mathrm{~km}$ long, facing the Bay of Bengal in the south. It has rocks and boulders in only about half a $\mathrm{km}$ stretch along the Inani Beach and huge in number around the St. Martin's Island (SMI). The intertidal and drifted seaweed flora of these areas, specially the St. Martin's Island is rich. So far, 197 species of seaweeds (of them 95 are red, 46 greens and 56 brown) have been recorded (Ahmed et al. 2008, 2009, Aziz and Islam 2009, Islam et al. 2010, Aziz and Rahman 2010, 2011). But the study of sublittoral seaweeds is meager, mainly due to lack of facilities like SCUBA divers, and underwater communication systems with video. Recently, attempt was undertaken to enlist exclusively the submerged seaweed species present, their diversity, distribution and standing biomass in the SMI taking all types of support from the Bangladesh Navy. The present paper includes only the floristic account of the submerged seaweeds, while the species diversity, distribution and standing biomass of submerged seaweeds of the island are included elsewhere.

\section{Materials and Methods}

Seaweeds were collected from 0.5 to $10 \mathrm{~m}$ depth during late March and April, 2013 from six localities of the SMI, taking the help of SCUBA diving team of the Bangladesh Navy.The samples were then preserved in sea water with $5 \%$ formalin, and individual seaweed as herbaria, deposited in the Department of Botany, University of Dhaka. A total of five locations in March (A-D, F) and five in April (A-E) were considered around the island (Map 1).

\section{Results and Discussion}

In the present investigation a total of 39 seaweed taxa, 12 under Rhodophyceae, 11 under Chlorophyceae and 16 under Phaeophyceae have been worked out, illustrated and discussed. 


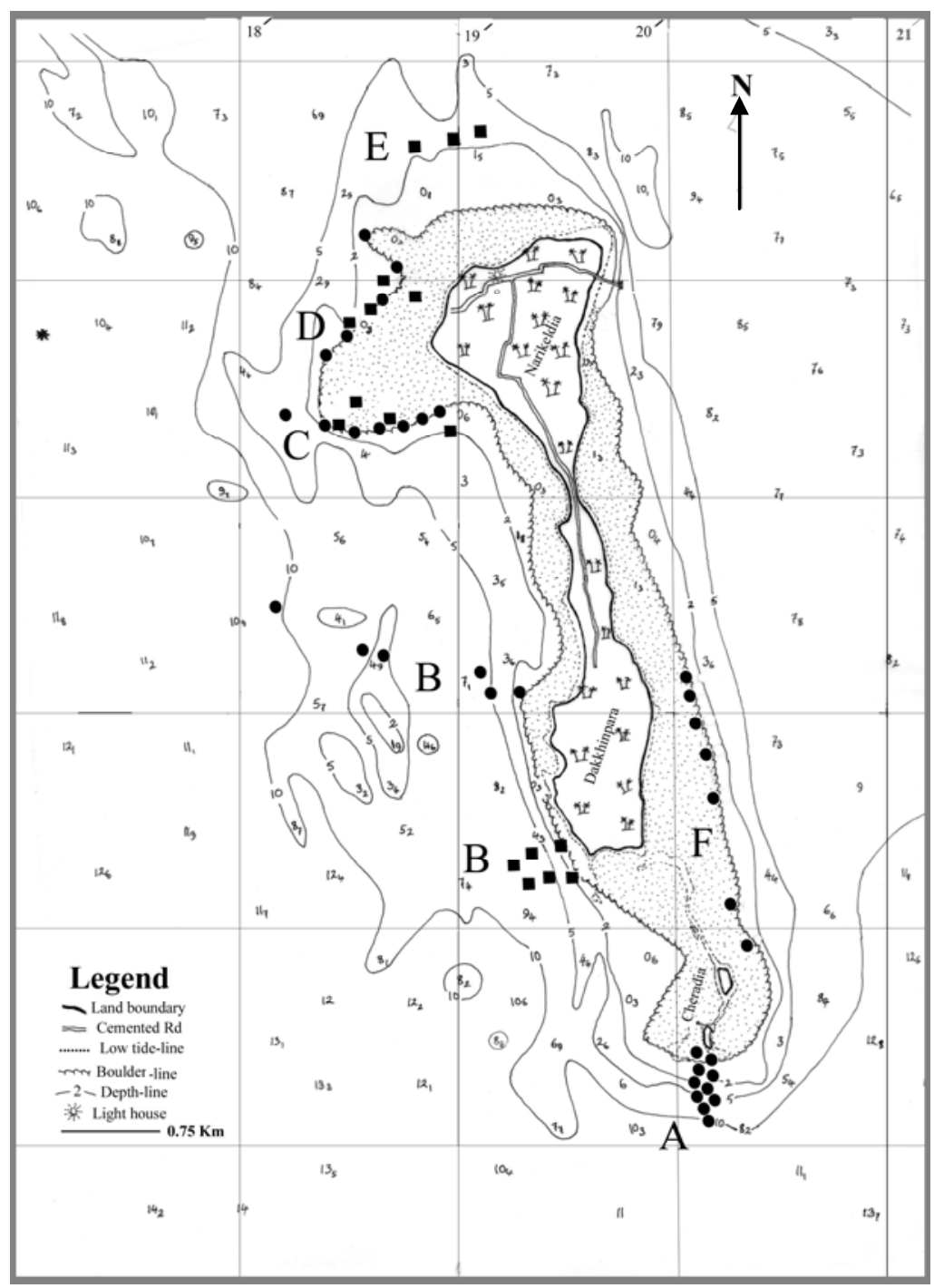

Map 1. St. Martin's Island, showing six locations A to F of sublittoral seaweed collections made on March (•) and April (ロ) 2013. Boulder-line (wavy) and depth profile (in meter) around the island and further, during low tide are also shown. A survey was done at $15 \mathrm{~m}$ depth in the upper left by video communication system $(*)$.

\section{Rhodophyceae}

Sub-class: Floridiophyceae; Order: Nemalionales; Family: Chaetangiaceae Genus: Galaxura Lamax.

\section{Galaxura fastigiata Decaisne}

(Islam 1976, Pl. 62, Fig. 368)

Locality: Location E, at a depth of 0.9, 1.7 meters. 


\section{Order: Cryptonemiales; Family: Coralliniaceae Genus: Jania Lamax.}

2. Jania ungulata (Yendo) Yendo

(Syn. Corallina ungulata Yendo 1902)

(Islam 1976, Pl. 65, Figs 383-386)

Locality: Location A, at a depth of 0.3 meter; Location C, at a depth of 1.7, 4.0, 6.0 meters; Location F, at a depth of 1.5 meter; Location $\mathrm{C}$, at a depth of 0.2, 0.3, 1.6, 3.0 meters; Location E, at a depth of 1.7 meter.

\section{Order: Gigartinales; Family: Hypneaceae Genus: Hypnea Lamax.}

\section{Hypnea musciformis (Wulf.) Lamx}

(Syn. Fucus musciformis Wulfen in Jacquin 1789, Hypnea rissoana J. Ag. 1842, Hypnophycus musciformis (Wulfen) Kütz. 1843, Hypnea arborescens P.L. Crouan \& H.M. Crouan 1865) (Bǿrgesen 1915-20, 384; 1937, 47; 1938, 221; 1939, 112; Islam 1976, Pl. 55, Fig. 245).

Locality: North west of Dakshinpara (Location B), at a depth of 5.0 meter; west of Light house (Location D), at a depth of 0.2, 1.5, 1.9 meters; west of Coral view guest house (Location C), at a depth of 1.5, 2.0 meters; east of Dakshinpara (Location F), at a depth of 1.6 meter; north of Light house (Location E), at a depth of 1.7 meter.

\section{Order: Bonnemaisoniales; Family: Bonnemaisoniaceae Genus: Asparagopsis Montagne}

4. Asparagopsis taxiformis (Del.) Coll. et Harvey

(Syn. Fucus taxiformis Delile, Lictoria taxiformis (Delile) J. Ag. 1841, Asparagopsis sandfordiana Harvey 1855)

(Islam 1976, 57-58, Fig. 370; Pham-Hong 1969, 216, Fig. 2.149)

Locality: South of Cheradia (Location A), at a depth of 0.2, 1.2 meters; east of Modhapara (Location E), at a depth of 0.2, 5.7 meters.

\section{Order: Ceramiales; Family: Dasyaceae Genus: Dasya C. Ag.}

5. Dasya corymbifera J. Ag.

(Syn. Callithamnion corymbiferum (Kützing) Trevisan 1845, C. corymbiferum (Kützing) Zanardini 1847, Dasya venusta Harvey 1849)

(Islam S et al. 2010, 89, Fig. 2A-E)

Locality: West of Coast Guard (Location C), at a depth of 0.3, 3.0 meters; at 3.0 meter the alga was associated with at the base of the Avrainvillea amadelpha.

6. Dasya pedicellata (C. Ag.) C. Ag.

(Syn. Sphaerococcus pedicellatus C.Agardh)

(Islam 1976, Pl. 55, Figs. 333-334; Pham-Hoang, 1969, 245, Fig. 2.176)

Locality: West of Coast Guard Office (Location C), at a depth of 0.2, 3.0 meters; at 3.0 meter the alga was associated with at the base of the Avrainvillea amadelpha. 


\section{Family: Rhodomelaceae}

Genus: Gracilaria Grev.

7. Gracilaria spinuligera Bǿrg.

(Aziz et al. 2002, 114-115, Figs 7-8)

Locality: West of Coast Guard Office (Location C), at a depth of 2.5 meter.

Genus: Neurymenia J. Ag.

8. Neurymenia fraxinifolia (Mertens ex Turner.) J. Ag.

(Fig. 1)

(Syn. Fucus fraxinifolius Mertens ex Turner 1809; Neurymenia fraxinifolia var. australis J.

Ag. 1863; N. fraxinifolia var. madagascarensis J. Ag. 1863)

(Chowdhury and Ahmed 2007, 81-82, Figs 1-4).

Locality: Location C, at a depth of 1.7 meter.

\section{Family: Delesseriaceae}

\section{Genus: Vanvoorstia J. Ag.}

9. Vanvoorstia coccinea Harvey ex J. Agardh.

(Islam 1976, PI. 71, Figs a-e)

Locality: East of Dkshinpara (Location F), at a depth of 2.5 meter.

\section{Order: Cryptonemiales; Family: Grateloupiaceae}

Genus: Halymenia C. Ag.

10. Halymenia floresia (Clemeente) C. Ag.

(Syn. Fucus floresii Clemente1807).

(Islam and Aziz 1987, 213-214, Fig. 20, Taylor 1960,418, Pl. 45, Fig. 12; Pl. 51, Fig.3)

Locality: West of Coral view guest house (Location C), at a depth of 0.9 meter; east of Modhapara (Location E), at a depth of 1.5 meter.

\section{Halymenia (?) floridana J. Ag.}

(Syn. H. bermudensis Coll. et Howe 1916; H. gelinaria Coll. et Howe 1916)

(Aziz and Rahman 2010, 164-165, Figs 3A-C; Taylor 1960, Pl. 53, Fig. 2).

Locality: South west of Dakshinpara (Location B), at a depth of 0.3, 7.1 meters.

\section{Family: Squamariaceae}

\section{Genus: Peyssonnelia Decasine}

12. Peyssonnelia polymorpha (Zanard.) Schmitz.

(Syn. Lithymenia polymorpha Zonard.)

(Aziz 1997, 81-82, Figs 1-4)

Locality: Location A, at a depth of 0.2, 0.3, 2.5, 4.0 meters; Location C, at a depth of 0.3, 2.5 meters, Location D, at a depth of 0.2, 0.3, 2.5, 4.0, 15 meters, on older parts of a live coral, near to Pocockiella and growing Halimeda. 


\section{Chlorophyceae \\ Order: Cladophorales; Family: Cladophoraceae \\ Genus: Cladophora Kütz.}

13. Cladophora prolifera (Roth) Kütz.

(Syn. Conferva prolifera Roth 1797, Cladophora multifida Brand, C. scoparia Kütz. 1845, Conferva scoparia (Kütz.) Zanardini 1847, Cladophora prolifera var. confertissima Kütz. 1849, C. prolifera var. firma Kütz. 1849, C. prolifera var. flaccida Kütz. 1849, C. prolifera var. scoparia (Kütz.) Schiffner1931)

(Aziz et al. 2010, 195-196, Fig. 1 A-D)

Locality: West of Bangladesh Coast Guard (Location C), at a depth of 0.2, 0.3, 0.5, 0.9, 1.5 meters.

\section{Order: Codiales; Family: Codiaceae \\ Genus: Codium Stackhouse}

14. Codium geppei Schmidt

(Syn. C. divaricatum Gepp \& Gepp 1911)

(Børgesen 1946, 49-52, Figs 19-22; Islam and Khair 1978, Pl. 1; Fig 1; Pl. 2, Fig.18)

Locality: East of Dakshinpara (Location F), at a depth of 1.5 meter.

\section{Order: Siphonales; Family: Codiaceae \\ Genus: Avrainvillea Decsane}

15. Avrainvillea amadelpha (Montagne) Gepp et Gepp

(Fig. 2)

(Syn. Udotea amadelpha Montagne 1857; Avrainvillea lacerata var. robustior Gepp et Gepp 1911)

(Børgesen 1948, 33-34, Fig. 14)

Plants with a large hapteron, short stipe with fan-shaped expanded cushion-like irregular structure; holdfast firmly fixed to the substratum, from which a great number of erect fan shaped shoots arise. The erect shoots are densely placed, about $3-5 \mathrm{~cm}$ high. They have a short up to about $1 \mathrm{~cm}$ long, vigorous stripe. This is often ramified, giving out a single or some few erect shoots. The fan shaped flabellum is about $3-4 \mathrm{~cm}$ broad with a semicircular or more irregularly upper outline. The flabellum is of a soft and rather loose consistency, especially near the upper margin with concentric rings. Holdfast about $1.5 \mathrm{~cm}$ diameter forms a moderately hard structure. Calcium carbonate layer forms on the surface of the holdfast. Jania filaments (about $0.5 \mathrm{~mm}$ diameter) developed from the lower side of the holdfast. On the surface of the older blade several semi circular concentric calcified thalli developed. On the margin several branched red algae (Daysa corymbifera and D. pedicellata) grew.

Locality: West of Coast Guard Campus (Location C), at a depth of 3.0 meter.

\section{Order: Caulerpales; Family: Caulerpaceae Genus: Caulerpa Lamour.}

16. Caulerpa cactoides (Turner) C. Ag.

(Syn. Ahnfeldtia cactoides (Turner) Trevisan, Fucus cactoides Turner 1809, Caulerpa cactoides var. gracilis G.Murray 1891)

(Islam 1976, PI. 12, Figs 94-95; Pl. 14 Fig. 103) 
Locality: South of Cheradia (Location A), at a depth of 4.0-10.0 meters and East of Dakshinpara (Location C), at a depth of 0.2, 0.3, 1.5 meters.

17. Caulerpa chemnitzschi (Esper) Weber- van Bosse

(Fig. 3)

(Syn. C. peltata Lamx., C. racemosa (Forssk.) C. Ag. var. peltata (Lamx.) Eubank 1946)

(Islam 1976, Figs. 50-52; Pl. 12, Fig. 93 Nizamuddin 1964, 205, Pl. III; Bøergesen, 1932, 62, Fig 5a; Guiry and Guiry 2014).

Locality: South of Cheradia (Location A), at a depth of 1.5, 4.0, 6.0, 7.0 meters and west of Bangladesh Coast Guard Office (Location C), at a depth of 3.0 meter.

18. Caulerpa chemnitzschi var. occidentalis (J. Ag.) Børgesen.

(Fig. 4)

(Syn. C. racemosa var. occidentalis J. Ag. 1873, in Taylor 1960, 153, Pl. 17, Fig. 6) (Guiry and Guiry 2014)

Locality: West of Bangladesh Coast Guard (Location C), at a depth of 0.2, 1.5, 4.0 meters; east of Dakshinpara (Location F), at a depth of 1.5 meter.

\section{Caulerpa racemosa var. clavifera (Turner) Weber- van Bosse}

(Islam 1976, 19-20, Figs 40 - 41; Taylor 1950, 62; 1960, 152 Pl. 17, Fig. 7)

Locality: West of Coast Guard (Location C), at a depth of 0.2, 0.3, 1.5, 4.0 meters; East of Dakshinpara (Location F), at a depth of 1.5 meter.

20. Caulerpa sertularioides fa brevipes (J. Ag.) Svedelius

(Fig. 5)

(Syn. C. plumaris var. brevipes J. Ag.)

(Taylor 1960, 144, Pl. 13, Figs 2 - 3)

Locality: North-west of Dakhshinpara (Location B), at a depth of 5.0 meter and west of Light house (Location D), at a depth of 0.2, 0.4, 0.91 .5 meters.

\section{Caulerpa taxifolia (M. Vahl) C. Ag.}

(Fig. 6)

(Syn. Fucus taxifolius Vahl 1802, Caulerpa pennata J.V. Lamx 1809, C. falcata Kütz 1857) (Islam 1976, 22 - 23, Figs 49, 68 - 69, 88)

Locality: South of Cheradia (Location A), at a depth of 0.2, 1.6, 10 meters; west of Light house (Location D), at a depth of 1.5, 1.9, 3.1, 3.5, 10, 15 meters; west of Coral view guest house (Location C), at a depth of 1.5, 1.7 meters. It is one of the commonest Caulerpa sp. abundantly growing in shallow water in rather exposed areas, in large thick turfs on rocks or stones and mixed up with Halimeda sp.

\section{Halimeda discoidea Decaisne}

\section{Family: Udotiaceae \\ Genus: Halimeda}

(Syn. H. discoidea Kütz. 1857)

(Islam 1976, Pl. 4, Fig. 39; Pl. 13, Fig. 97 - 98; Bøergesen, 1913, 106, Fig. 86)

Locality: West of Coast Guard Office (Location C), at a depth of 1.5 - 3.0 meters; North-west of Dakshinpara (Location B), at a depth of 5.0 meter; west of Light house (Location D), at a depth of 1.5 meter; west of Coral view guest house (Location C in April), at a depth of 1.5 meter; west of Light house (Location D in April), at a depth of 0.9 - 15.0 meters; north of Light house (Location E), at a depth of 1.7 meter; east of Dakshinpara (Location F), at a depth of 1.5 meter. 


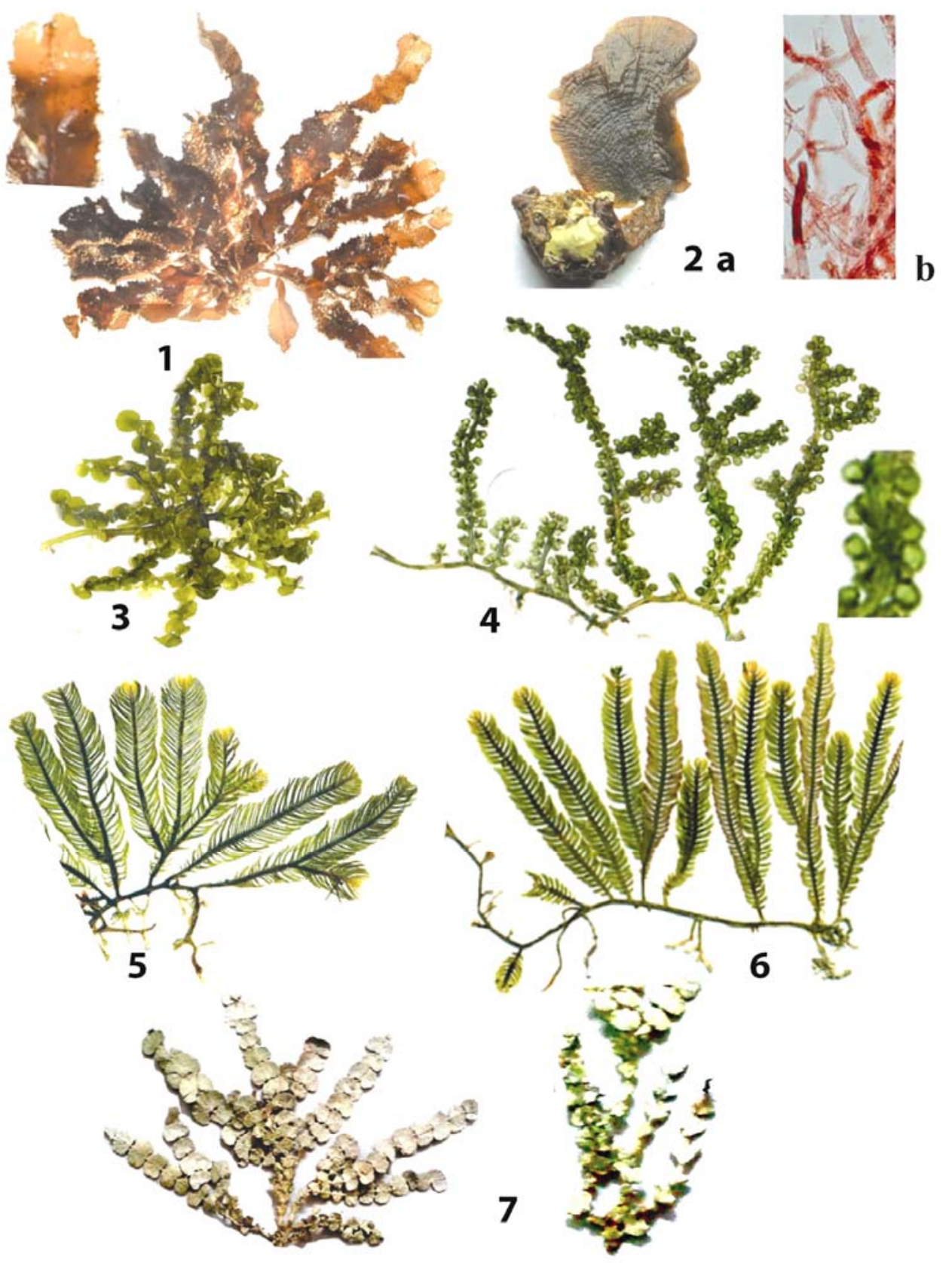

Figs 1 - 7: 1. Neurymenia fraxinifolia, $\times 0.40 .2$ (a-b). (a) Avrainvillea amadelpha, a whole plant with stumplike holdfast, $\times 1$; (b) Photomicrograph of a coenocytic filaments. 3. Caulerpa chemnitzschi $\times 0.5$, a part of a live plant. 4. C. chemnitzschi var. occidentalis, $\times 0.60$, herbarium. 5. C. sertularioides fa. brevipes, $\times 0.30$, herbarium. 6. Caulerpa taxifolia $\times 1$, herbarium. 7. Halimeda opuntia, two ecotypes $\times 0.3$, herbarium. 
23. Halimeda opuntia (L.) Lamx.

(Fig.7)

(Syn. Corallina opuntia Linn. 1758)

(Islam 1976, Pl. 13 Fig. 96; Taylor 1960, 176-177, Pl. 23, Fig. 3; Pl. 24, Fig. 1)

Plants whitish green, well calcified, of moderate height, $4-8 \mathrm{~cm}(20 \mathrm{~cm})$ high; 5 to $10 \mathrm{~cm}$ wide, spreading laterally to form large colonies attaching at various points but with no persisting primary base; densely branching in all planes, successive branches and successive segments often at right angles with each other; segments with a truncate lower margin or becoming slightly pedicellate, transversely oval to reniform or a little trilobed, 3 radiating ribs being distinctly visible on the surface; segments about 2.5 to $10.0 \mathrm{~mm}(20 \mathrm{~mm})$ wide, 0.3 to $0.7 \mathrm{~mm}(12.00 \mathrm{~mm})$ long; surface utricles $20-50 \mu$ diam. in surface view, in section rarely $70 \mu$ long, the side walls in contact for about 0.078 of their length; medullary filaments incompletely fused, generally in pairs, at the nodes, an opening developing at the point of contact, but each member of the pair continuing upward and dividing dichotomously independently of the other. $H$. incrassata (Ellis) Lamox. (Taylor 1960, Pl 23, Figs. 1, 4) has been created based on having triangular lobes in about lower half of the axis. In H. opuntia ( L) Lamox. the lower most $2-3$ segments were invariably triangular, thus $H$. incrassata has been considered as ecotype of $H$. opuntia.

Locality: Location A, at a depth of 0.2, 0.3, 2.5, 2.9, 8.0 meters in association with Caulerpa peltata; Location C, at a depth of 1.5, 4.0 meters; Location B, at a depth of 5.0 meter; Location D, at a depth of 1.5 meter; Location C (in April), at a depth of 1.5 meter; Location F, at a depth of 1.5 meter; Location E, at a depth of 2.0 meter.

\section{Phaeophyceae \\ Order: Dictyotales; Family: Dictyotaceae \\ Genus: Dictyota Lamx.}

24. Dictyota atomaria Hauck

(Syn. D. hauckiana Nizamuddin 1975)

(Islam et al. 2004, 1 - 2, Figs 1 - 3)

Locality: East of Dakshinpara (Location F), at a depth of 0.2, 1.5 meters; west of Light house (Location D), at a depth of 15 meter.

Genus: Dictyopteris Lamx.

25. Dictyopteris australis Sonders in Askenasy.

(Syn. Haliseris australis Sonder 1853, H. pardalis Harvey 1855, Neurocarpus pardalis

(Harvey) Küntze 1898)

(Islam 1976, 38, Pl. 39, 240)

Locality: Location B, at a depth of 0.3, 7.0 meters; Location C, at a depth of 2.0, 4.0, 6.0 meters; Location D, at a depth of 1.0, 1.7 meters; Location C (in April), at a depth of 1.5 meter; Location D (in April), at a depth of 1.5, 1.7 meters.

\section{Padina tenuis Bory.}

\section{Genus: Padina Adanson} 1828)

(Syn. Vaughaniella rupicola Børgesen 1950, Padina commersonii Bory de Saint-Vincent

(Islam 1976, Pl. 43. Figs 252-254, PI. 44, Figs 256-257;)

Locality: East of Dakshinpara (Location F), at a depth of 0.2, 1.5, meters. 
27. Padina pavonica (L.) Thivy

(Islam 1976, Pl. 45, Fig. 260)

Locality: West of Coast Guard Office (Location C), at a depth of 0.2, 1.5 meters.

28. Padina gymnospora (Kütz.) Sonder

(Syn. P. vikersiae Hoyt in Howe 1920, Zonaria gymnospora Kütz 1859)

(Islam 1976, Pl. 43, Fig. 255)

Locality: North-west of Dakshinpara (Location B), at a depth of 0.2, 4.5, 6.0 meters.

Genus: Pocockiella Papenfuss

29. Pocockiella variegata (Lamx.) Papenfuss

(Fig. 8)

(Syn. Spatoglossum nigrescens (Sonder) Kütz. 1849, Orthosorus nigrescens (Sonder) Trevisan 1849, Pocockiella nigrescens (Sonder) Papenfuss 1943)

(Taylor 1960, Pl. 33, Fig. 4)

Plants with holdfast, short stipe and wide blades, $3-8 \mathrm{~cm}$ high, width similar to height or wider, attached by rhizoids form the bases of the blades; dark-brown, not much changed in colour by drying; decumbent to erect; thallus little cleft, becoming broadly deltoid to suborbicular or kidney-shaped, the lobes $3-7 \mathrm{~cm}$ broad; a few concentric rings present, margin involucre with many sori present; distinct radial cells visible with naked eyes; the marginal row of apical cells developing a single layers of large medularry cells covered by $1-2$ subcortical layers and by a cortical layer of smaller cells; the number of subcortical layers usually equal on both sides of the blade, which is $100-300 \mu \mathrm{m}$ thick; cortical cells overlying the medullary cells about 8 on one face and only 4 on the other. A number of fronds 3 to 10 may grow together.

Locality: South of Cheradia (Location A), at a depth of 2.5 meter; west of Coral view guest house (Location C), at a depth of 1.5 meter.

\section{Genus: Spatoglossum Kützing}

\section{Spatoglossum variabile Figari et De Notaris}

(Fig. 9)

(Guiry and Guiry 2014)

Thallus about $42 \mathrm{~cm}$ long, basal part rhizomatous compact disc, upper part irregularly to subdichotomously divided; branch segments $1-3 \mathrm{~cm}$ broad, attenuated at the bases and apices; margins provided with small teeth and frequent proliferations of various sizes. Thallus composed of palisade-like superficial layer of cells, $47-74 \mu \mathrm{m}$ broad with abundant chromatophores enclosing about 3 - 4 layers of inner cells; medulla cells 47 - $60 \mu \mathrm{m}$ broad; angular, thick walled, isodiametric to horizontal with few chromatophores, 107 - $134 \mu \mathrm{m}$ long, $53.6-67.0 \mu \mathrm{m}$ broad; reproductive structures scattered over the surfaces; tetrasporangia globular, usually occurring singly.

Locality: West of Coast Guard (Location C), at a depth of 0.4, 0.9, 1.5, 1.6, 1.7, 4.0 meters; Location B, at a depth of 0.3, 1.4, 1.7, 6.0 meters; Location D, at a depth of 1.0, 1.7, 7.0 meters.

\section{Spatoglossum asperum $\mathrm{J}$. Ag.}

(Fig.10)

(Guiry and Guiry 2014)

Plants up to $45 \mathrm{~cm}$ high, stipe branched dichotomously (sometimes trichotomously), branches strap-shaped, up to $6 \mathrm{~cm}$ wide, gives golden coloured tint when a herbarium is made with freshly collected material. The base of each strap is narrow, gradually widens and then slightly narrowed in to nearly pointed to broadly rounded tips; margins develops $1-1.5 \mathrm{~mm}$ long teeth mostly in the 

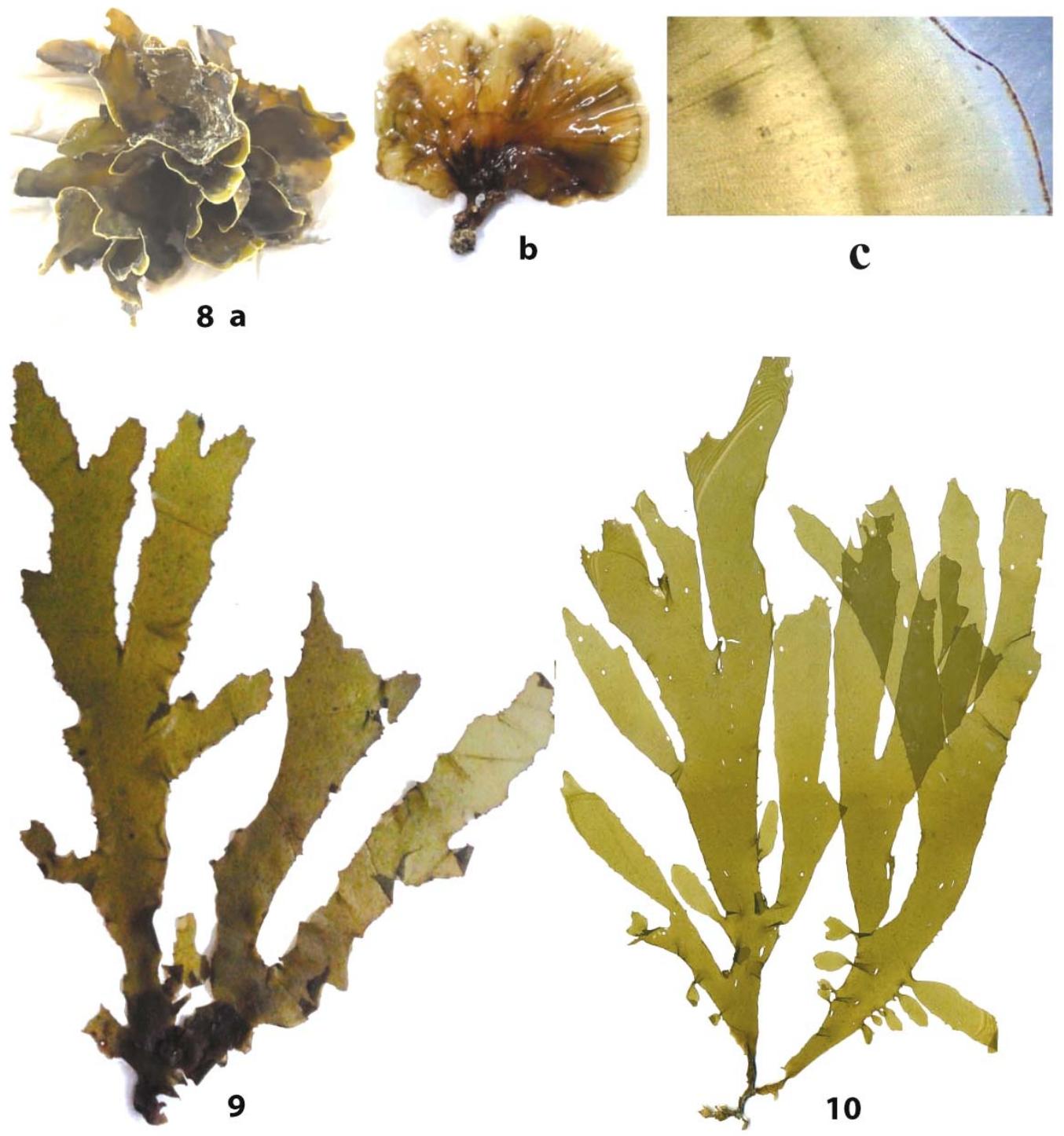

Figs 8-10: 8(a-c). Pocockiella variegata, $\times$ 0.60, (a) Aggregate of eight live thalli top view, (b) Herbarium of a thallus, (c). Photomicrograph of a part of the frond showing radiating and concentric nature of the thallus with sori in the margin. 9. Spatoglossum variabile, $\times 0.30$, herbarium.10. S. asperum, $\times 0.24$, herbarium of a whole plant.

lower part of the frond. Adventitious branches may develop from lower most $1 / 5$ to $2 / 5$ of thallus length; straps contain circular to elliptrical and cylindrical rod shaped wholes distributed all along irregularly. Around sporangial initials $(2-4)$ at a circumference of about $1 \mathrm{~mm}$, about 10 cells arranged almost radialy, which are gradually raised and relative browner towards the sporangial initial; and on the surface of each of these cells there appears to be produced 15 to 20 short rod to spherical structures almost in a circular pattern. Transverse section of the thallus revealed 9 to 10 cell layers where the medulary layer is very large followed by gradually smaller (compressed) cortical cells. 
Spatoglossum asperum J. Ag. was recorded by Islam et al. 2004, the anatomical description of which fits with S. schroederi (Martens) Kg. (Joly 1965, Pl. 10, Figs 143 - 144).

Locality: Location C, at a depth of 0.4 meter; Location $\mathrm{D}$, at a depth of $0.5,1.5$ meters.

\section{Order: Dictyosiphonales; Family: Chnoosporaceae Genus: Chnoospora J. Agardh.}

32. Chnoospora implexa Hering ex J. Ag.

(Syn. Dictyota obtusangula Kützing 1859, Chnoospora obtusangula (Harvey) Sonder 1871)

(Islam 1976, Pl, 41. Figs 245 - 246)

Locality: West of Coast Guard (Location C), at a depth of 1.5 meter; east of Dakshinpara (Location F), at a depth of 1.6 meter; north of Light house (Location E), at a depth of 1.6 meter. The seaweed is abundant on the east coast of SMI.

\section{Order: Fucales; Family: Sargassaceae Genus: Sargassum CA Ag.}

33. Sargassum coriifolium J. Ag.

(Syn. S. lanceolatum Greville 1848)

(Aziz et al. 2001, 135, Figs 3 - 4, 13; Womersley and Bailey 1970, 295, Fig. 6, Pl 24, Fig. 14)

Locality: East of Dakshinpara (Location F), at a depth of o.2, 1.5 meters.

34. Sargassum olygocystum Mont

(Syn. S. binderi Sonder. in Agardh. 1848)

(Aziz et al. 2001, 140, Figs 8 - 9, 16)

Locality: South of Cheradia (Location A), at a depth of 3.0 meter.

35. Sargassum swartzii (Turner) C. Ag.

(Aziz et al. 2001, 140, Figs 10 - 11, 17A-C)

Locality: East of Dakshinpara (Location E), at a depth of 0.9, 2.5 meters; west of Coast Guard Office (Location D), at a depth of 2.5 meter.

36. Sargassum tenerrimum J. Ag.

(Fig. 11)

(Islam 1976, Fig. 264)

Locality: South of Cheradia (Location A), at a depth of 10.0 meter.

37. Sargassum pallidum (Turner) C. Agardh

(Fig. 12)

(Yoshida 1983, 134 - 136, Fig. 17)

Plants $50 \mathrm{~cm}$ high; primary branch produce secondary branches at a regular interval; the secondary branch branches again which are modified in to fronds (leaves), air bladders and receptacles; leaves oblong to ovate, tips obtuse to pointed, 2.5 to $5.5 \mathrm{~cm}$ long, 1.0 to $1.5 \mathrm{~cm}$ broad with wavy to light dentatations on the margin, midrib slightly distinct, cryptostomata not visible; air bladders ovoid, $4-8 \mathrm{~mm}$ long and $3-5 \mathrm{~mm}$ broad without leafy outgrowth; receptacles brownish, swollen, partly cylindrical, in to four relatively smooth branches.

Locality: South of Cheradia (Location A), at a depth of 6.0 meter. 


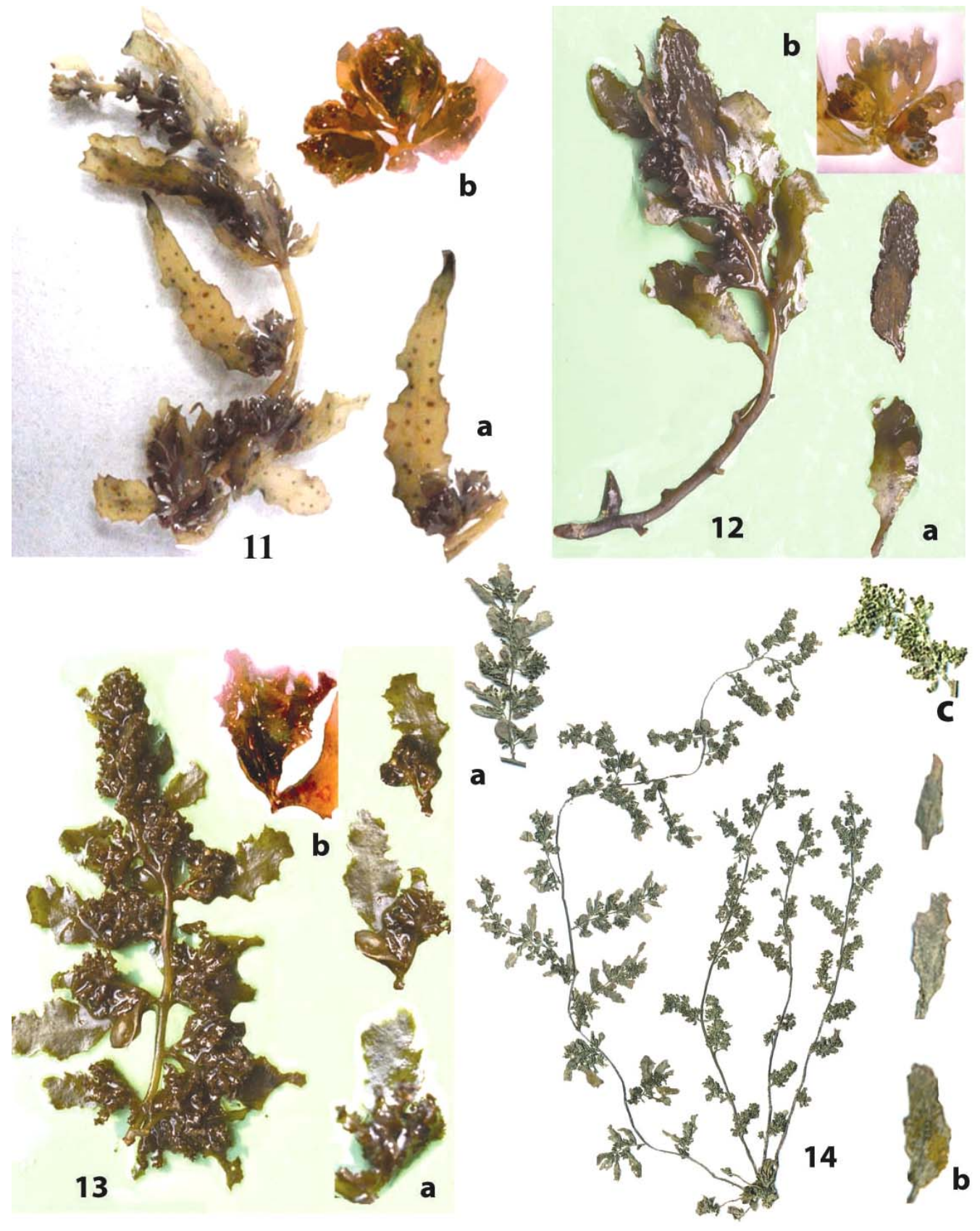

Figs 11-14: 11. Sargassum tenerrimum, a portion of the plant, $\times 0.28$; (a) enlarged tertiary branch showing receptacles, air bladder and the frond, (b) an enlarged branched receptacles. 12. Sargassum pallidum, $\times$ 0.16 , a portion of the preserved plant; (a) fronds and (b) a branched receptacle enlarged. 13. Sargassum sp. (1), $\times 0.10$, a portion of the plant, (a) tertiary branches and (b) a branched receptacle enlarged. 14. Sargassum sp. (2), $\times 0.27$, herbarium, (a) a portion of the secondary branch, (b) fronds and (c) a branched receptacle enlarged. 
38. Sargassum sp. (1)

(Fig. 13)

Plants $70 \mathrm{~cm}$ high; primary branch produce secondary branches at a regular interval; the secondary branch branches again which are modified in to fronds (leaves), air bladders and receptacles; leaves thick, oblong, tips blunt, 2.5 to $5.5 \mathrm{~cm}$ long, 1.0 to $1.9 \mathrm{~cm}$ broad with deeply notched margins, little dentations, midrib region swollen, distinct, cryptostoma absent; air bladders robust ovoid, $1.0-1.3 \mathrm{~cm}$ long up to $7.0 \mathrm{~mm}$ broad with leafy spiny margins; receptacles robust, profusely branched, cylindrical with spiny projections from around.

Locality: South of Cheradia (Location A), at a depth of 0.9 meter.

\section{Sargassum sp. (2)}

(Fig. 14)

Plants usually up to $40 \mathrm{~cm}$ tall; holdfast strong producing a very short type that gives rise to four robust primary branches; primary branches produce secondary branches alternately at 2.7 $3.2 \mathrm{~cm}$ interval; secondary branches relatively short which tertiary branches again at regular interval and modified in to fronds (leaves), air bladders and receptacles; leaves nearly lanceolate with obtuse to pointed tip, $2.5-3.6 \mathrm{~cm}$ long, $0.7-1.2 \mathrm{~cm}$ broad with lightly undulated spiny margins, midrib indistinct, cryptostomata lacking; air bladders ovoid to ellipsoidal, 6 - $8 \mathrm{~mm}$ long; secondary branches are transformed into tertiary branches or repeatedly branched cylindrical receptacles, with spines around.

Locality: West of Light House (Location D), at a depth of 5.0 meter.

\section{Acknowledgements}

Heartfelt gratitude to the Bangladesh Navy authority for providing the Naval Ship and Scuba Divers with Underwater Photographic and Communication Systems to carry out the research in the bottom of the sea. Special thanks to Commander M. Zahid Hossain, (TAS), Psc Co BNS SAIKAT for providing all out help for four days in the sea.

\section{References}

Ahmed ZU, Begum ZNT, Hassan MA, Khondker M, Kabir SMH, Ahmad M, Ahmed ATA, Rahman AKA and Haque EU (eds.) 2008. Encyclopedia of Flora and Fauna of Bangladesh. Vol. 3. Algae, Chlorophyta (Aphanochaetaceae-Zygnemataceae). Asiat. Soc. Bangladesh, Dhaka. pp. 812

Ahmed ZU, Khondker M, Begum ZNT, Hassan MA, Kabir SMH, Ahmad M, Ahmed ATA and Rahman AKA (eds.) 2009. Encyclopedia of Flora and Fauna of Bangladesh.Vol. 4. Algae, CharophytaRhodophyta, (Achnanthaceae- Vaucheriaceae). Asiat. Soc. Bangladesh, Dhaka. pp. 543

Aziz A and Islam S 2009. Marine algae of the St. Martin's Island, Bangladesh.VII. Acrochaetium nurulislamii sp. nov.and new records of Acrochaetium (Rhodophyceae). Bangladesh J. Bot. 38(2): 145151.

Aziz A and Rahman MT 2010. Marine algae of the St. Martin's Island, Bangladesh. XI. Red algae (Rhodophyceae). Bangladesh J. Bot. 39(2): 161-168.

Aziz A and Rahman MT 2011. Marine algae of the St. Martin's Island, Bangladesh. XII. New records of Red and green algae. Bangladesh J. Bot. 40(1): 41-45.

Aziz A, Islam S and Chowdhury AH 2010. Marine algae of St. Martin's Island, Bangladesh-IX.New records of green algae (Chlorophyceae). Bangladesh J. Plant Taxon.17(2): 193-198.

Aziz A, Islam AKMN and Jahan A 2002. Marine algae of St. Martin's Island, Bangladesh. IV. New rwecords of red algae. Bangladesh J. Bot. 31(2): 113-116.

Aziz A, Islam AKMN and Pervin R 2001. Marine algae of St. Martin's Island, Bangladesh. I. New records of Sargassum spp. Bangladesh J. Bot. 30(2): 135-140. 
Børgesen F 1913.The marine algae of the Danish West Indies. I. Chlorophyceae. Dansk Bot. Arkiv. 1(4): 1$158+2$, Figs, map.

Børgesen F 1915-20. The marine algae from Danish West Indies. Dansk. Bot. Arkiv. 3:384

Børgesen F 1937a. Contribution to a South Indian marine algae flora. Jour. Ind. Bot. Soc. 16 (1-2); 1-56.

Børgesen F 1932. A revision of Forsskail's algae mentioned in Flora Aegyptico-Arabica and found in his herbarium in the Botanical Museum of the University of Copenhagen. Dansk Bot. Arkiv. 8(2): 1-15, 4 text Figs, 1 pl.

Børgesen F 1937-1938. Contribution to a south Indian marine algal flora 1 - 3. - J. ind. Bot. Soc. Vol. 16-17, Madras.

Børgesen F 1939. Bushire and the Island Kharg. - Danish Scient invest. in Iran, Part 1. Kǿben-havn.

Børgesen F 1946. Some marine algae from Mauritius: Additional list of species to Part I Chlorophyceae DetKgl. DanskeVedenskabernes Selskab. Biolog. Meddelelser 20(6): 1-64

Børgesen F 1948. Some marine algae from Mauritius: Additional list to the Chlorophyceae and Pheophyceae. DetKgl. DanskeVedenskabernes Selskab.Biologiskemeddeleser 20 (12): 1-55 + 2 pl.

Chowdhury AH and Ahmed R 2007. Neurymenia fraxinifolia (Mert) J. Ag. A new record of a marine red alga for Bangladesh. Bangladesh J. Bot. 36(1): 81-83.

Guiry MD in Guiry MD and Guiry GM 2014. AlgaeBase. World-wide electronic publication, National University of Ireland, Galway. http://www.algaebase.org; searched on 01 January 2015.

Islam AKMN 1976. Contribution to the study of the marine algae of Bangladesh. Bibliotheca Phycologica 19: $1-253$.

Islam AKMN and Aziz A 1987. Addition to the list of marine algae of St. Martin's Island, Bangladesh. III. Nova Hedwigia 45(1-2): 211-221.

Islam AKMN and Khair A 1978. Addition to the list of marine algae of St. Martin's Island. I. Genus Codium Stackhouse. J. Asiat. Soc. Bangladesh (Sci.) 3(2): 123-126.

Islam AKMN, Aziz A and Parvin R 2004. Marine algae of St. Martin's Island, Bangladesh. II. Brown Algae. Bangladesh J. Plant Taxon. 11(1): 1-7.

Islam S, Aziz A and Chowdhury AH 2010. Marine algae of St. Martin's Island, Bangladesh. VIII. New records of Red algae (Rhodophyceae). Bangladesh J. Bot. 39(1): 87-96.

Pham-Hoang Ho 1969. Marine algae of South Vietnam. Trung- Tam Hoc-Lieu Xuat- Ban.

Joly AB 1965. Flora marinha do littoral norte do estado de Sáo Paulo e Regioes circumvizinhas. Boletin No. 294. Fac. Fil. Cienc. E letr. Univ. Sáo Paulo, Bot. 21: 1-393.

Nizamuddin M 1964. Studies on the genus Caulerpa from Karachi. Bot. Marina. 6(3/4): 204-223.

Taylor RW 1950. Plants of Bikini and other northern Marshall Island. Univ. Mich.Stud. Ser. 18. Ann. Abor.

Taylor RW 1960. Marine algae of the eastern tropical \&subtropical coasts of the America. Univ. Mich. Press. Ann Abor. pp. 870

Womersley HSB and Bailey A 1970. Marine algae of Solomon island. Phil. Trans. Roy. Soc. London B 259 : 257-352.

Yoshida T 1983. Japanese species of Sargassum subgenus Bactrophycus (Phaeophyta, Fucales). J. Fac. Sci., Hokkaido Univ. Ser. V (Botany), 13(2): 99-246.

(Manuscript received on 3 March, 2015; revised on 10 April, 2015) 